\title{
IMPLIKATUR DALAM PERCAKAPAN SINETRON PARA PENCARI TUHAN
}

\author{
Dyah Rohma Wati \\ Akper 17 Karanganyar \\ Email: dyah.rohma87@gmail.com
}

\begin{abstract}
The aim of this research is to know conversational implicature in Para Pencari Tuhan (PPT) TV-series (volume I), especially to know and describe the kinds of maxim which float in PPT TV-series (volume I) and to describe the background of floating maxim in conversational implicature at PPT TV-series(volume I). This is qualitative research. The data of this research are conversational implicature of some utterances in PPT TV-series (volume I). The source of data is Para Pencari Tuhan TV-series (volume I, episode I) produced by PT Demi Gisela Citra Sinema. The researcher obtain the data through documentation technique. This technique starts by listening whole implicature in PPT TV-series (volume I), taking note whole related data, classifying and taking note the data in data card. This research uses flow model analysis to analyze the data, which include collecting data, data reduction, data presentation, and conclusion or verification. The data analysis show that there are floating in some coperative-principle of maxims, they are maxim quality (two utterances), maxim manner (two utterances), maxim relevance (one utterance). The floating maxim in PPT TV-series are influenced by some factors, they are the similarity of presupposition, the speaker refers to certain reference, and the use of local interpretation.
\end{abstract}

Keyword: implicature, conversational implicature, floating, cooperative principle, Para Pencari Tuhan (PPT) TV-series.

\begin{abstract}
ABSTRAK
Tujuan penelitian ini adalah untuk mengetahui implikatur percakapan dalam Sinetron Para Pencari Tuhan (PPT) Jilid I, khususnya untuk mengetahui dan mendriskripsikan maksim apa saja yang mengalami pengambangan serta latar belakang terjadinya pengambangan pada implikatur percakapan Sinetron Para Pencari Tuhan Jilid I. Penelitian ini merupakan penelitian kualitatif. Data dalam penelitian adalah implikatur percakapan yang terdapat dalam tuturan pemain sinetron PPT Jilid I. Sumber data penelitian adalah Sinetron Para Pencari Tuhan Jilid I episode I, yang diproduksi oleh PT Demi Gisela Citra Sinema. Data penelitian diperoleh dengan teknik dokumentasi. Teknik ini diawali dengan menyimak seluruh implikatur dalam Sinetron PPT Jilid I. Selanjutnya, peneliti mencatat seluruh data yang terkait, mengklasifikan serta mencatatnya kembali dalam kartu data.Teknik analisis data yang digunakan dalam penelitian ini adalah model analisis mengalir atau flow model analisis. Ada empat komponen dalam model analisis mengalir, yaitu pengumpulan
\end{abstract}


data, reduksi data, penyajian data, dan penarikan simpulan atau verifikasi. Analisis data menunjukkan adanya pengambangan dalam prinsip kerjasama maksim, diantaranya maksim kualitas(dua tuturan), maksim cara (dua tuturan), dan maksim relevansi (satu tuturan). Pengambangan pada percakapan Sinetron PPT Jilid I ini dipengaruhi oleh beberapa hal, diantaranya: adanya praanggapan yang sama, penutur mereferen pada referen tertentu, dan digunakannya interpretasi lokal.

Kata Kunci: Implikatur, implikatur percakapan, pengambangan maksim, prinsip kerjasama, sinetron para pencari tuhan

\section{PENDAHULUAN}

Bahasa berperan penting dalam kehidupan manusia. Manusia menggunakan bahasa untuk menyampaikan maksud mereka dalam berbagai kepentingan. Selain itu, keberadaan bahasa juga mempermudah manusia untuk saling berkomunikasi dan berinteraksi dengan manusia lainnya. Menurut Keraf dalam Sudaryono (1993:3), bahasa memiliki beberapa fungsi. Fungsi bahasa antara lain (1) untuk menyatakan ekspresi diri, (2) sebagai alat komunikasi, (3) sebagai alat untuk mengadakan integrasi dan adaptasi sosial dan (4) alat untuk mengadakan kontrol sosial. Kehidupan manusia sebagai makhluk sosial menuntut penggunaan bahasa untuk berinteraksi dan berkomunikasi dengan sesama.

Komunikasi antara penutur dan mitra tutur dapat berhasil jika prinsip-prinsip kerja sama terpenuhi. Prinsip kerja sama ini menekankan pada empat maksim. Maksim yang dimaksud adalah: (a) maksim kualitas (Maxim of Quality), (b) maksim kuantitas (Maxim of Quantity), (c) maksim relevansi (Maxim of Relevance), dan (d) maksim cara (Maxim of Manner). Secara garis besar, prinsip kerja sama menekankan pada adanya upaya kerja sama yang terjalin antara penutur dan mitra tutur dalam percakapan yang sedang berlangsung.

Bentuk implikatur, sebagai tuturan yang mengandung maksud implisit, sangat memerlukan prinsip kerja sama tersebut. Tuturan yang mengandung makna implisit atau implikatur ini kadangkadang tidak tampak pada penerapan maksim dalam prinsip kerja samanya. Jika percakapan berlangsung dengan baik, tidak terjadi kemacetan, maka tentunya terdapat penerapan prinsip kerja sama. Dalam percakapan sehari-hari, ditemukan beberapa fakta pelaksanaan prinsip kerja sama. Terdapat fakta adanya pematuhan dan pelanggaran prinsip kerja sama. Fenomena ini menunjukkan gejala penggunaan implikatur yang tidak sesuai dengan kaidahnya. Gejala yang I Dewa Putu Wijana menyebutnya sebagai bentuk penyimpangan. Namun, I Dewa Putu Wijana tidak menyebut implikatur yang tidak mengalami penyimpangan sebagai pematuhan.

Berikut contoh pematuhan maksim prinsip kerja sama.

(1) a. Kiki : Kamu tinggal dimana?

b. Koko : Ah, rumah saya cuma gubuk.

Kiki mengharapkan jawaban berupa nama tempat atau wilayah pemukiman karena ia menanyakan letak suatu tempat. Jawaban yang diterimanya justru bukan jawaban yang diharapkannya. Akan tetapi, dalam contoh di atas tidak tampak adanya pelanggaran maupun pematuhan maksim, yang terjadi adalah pengambangan. Pengambangan, semacam ada atau tidaknya pelanggaran maksim dalam percakapan yang bersangkutan.

Pemakaian bahasa dalam kehidupan dapat ditemukan dalam berbagai bidang, salah satunya dalam bidang hiburan khususnya film atau sinetron. Pada umumnya bahasa dalam sinetron menampilkan gambaran kehidupan. Di dalamnya terdapat percakapan-percakapan antartokoh. Percakapan-percakapan tersebut haruslah mempunyai keterkaitan agar penonton 
dapat memahami jalan cerita dari suatu film. Bahasa dalam film adakalanya berupa implikatur. Dengan implikatur, tuturan-turan dipandang lebih halus dan sopan. karena terkesan tidak to the point.

Sinetron Para Pencari Tuhan Jilid I merupakan sinetron bergenre religi-komedi. Sinetron ini bercerita tentang tiga mantan narapidana-Barong (Aden Bajaj), Juki (Isa Bajaj), dan Chelsea (Melky Bajaj) - yang keluar dari penjara dan harus menemui kenyataan bahwa mereka tidak diterima lagi di lingkungannya. Ketiga pemuda itu kemudian bertemu dengan Bang Jack, seorang marbot (penjaga) mushola dan mereka berniat untuk insyaf. Insyaf bukan hal mudah bagi mereka, karena mereka harus dilatih dengan baik dan benar disertai ketabahan dan kesungguhan. Kesulitan lain muncul ketika Bang Jack mencanangkan "bulan berburu rejeki halal". Ini jelas program yang sulit diikuti oleh Barong, Juki, dan Chelsea. Mereka terbiasa mencopet, mencuri motor, atau mengecer narkoba untuk mengais rejeki. Akhirnya, sedikit demi sedikit ketiga mantan narapidana itu mulai bisa memperbaiki diri.

Sejalan dengan hal tersebut, penelitian ini bertujuan untuk (1) mendiskripskan maksim apa saja yang mengambang dalam implikatur percakapan Sinetron Para Pencari Tuhan Jilid I. (2) menjelaskan latar belakang terjadinya pengambangan pada implikatur Percakapan Sinetron Para Pencari Tuhan Jilid I. Penelitian ini juga dapat memberikan manfaat, antara lain (1) mengembangkan penelitian tentang pengambangan implikatur percakapan dalam film/sinetron, (2) memperdalam pemahaman tentang adanya pengambangan dalam implikatur perckapan, (3) membantu pembaca untuk memahami latar belakang terjadi pengambangan implikatur percakapan dalam sinetron $P P T$ Jilid I.

Istilah implikatur dipakai oleh H.P Grice pada tahun I967 untuk menanggulangi persoalan makna bahasa yang tak dapat diselesaikan oleh teori semantik biasa (Lubis, I99I:70). Menurut Mei dalam Nadar (2008:60) implikatur "implicature" berasal dari kata kerja to imply sedangkan kata bendanya adalah implication. Kata kerja ini berasal dari bahasa latin plicare yang berarti to fold "melipat", sehingga untuk mengerti apa yang dilipat atau disimpan tersebut haruslah dilakukan dengan cara membukanya. Memahami apa yang dimaksudkan oleh seorang penutur, lawan tutur harus selalu melakukan interpretasi pada tuturan-tuturannya.

Chaer (2010:33) mengemukakan implikatur atau implikatur percakapan adalah adanya keterkaitan ujaran dari seorang penutur dan lawan tuturnya. Namun, keterkaitan itu tidak tampak secara literal: tetapi dapat dipahami secara tersirat. Jelas bahwa kalimat-kalimat yang secara lahiriah kita lihat tidak berkaitan, tetapi bagi orang yang mengerti penggunaan bahasa itu dapat menangkap pesan yang ditangkap oleh pembicara, seperti tuturan (2) antara A seorang ibu rumah tangga dengan B seorang ibu rumah tangga lain.

(2) a : Bapak x tetangga kita yang baru itu mobilnya sering ganti-ganti ya.

b : Tentu saja karena dia bekerja di kantor pajak.

Bisakah dipahami keterkaitan antara "sering ganti-ganti mobil" dengan "bekerja di kantor pajak?" Secara literal tidak bisa dipahami karena tidak disebutkan dalam pertuturan itu; tetapi secara tersirat bisa dipahami karena pada waktu sekarang kita tahu keadaan ekonomi seorang pegawai kantor pajak memang jauh lebih makmur dari pada yang tidak bekerja di kantor pajak (Chaer, 2010:33).

Grice (1975: 44) mengungkapkan bahwa implikatur terdiri dari dua jenis, yaitu implikatur konvensional dan implikatur percakapan. Implikatur Konvensional ialah implikasi atau pengertian yang bersifat umum dan konvensional. Semua orang pada umumnya sudah mengetahui dan memahami maksud atau implikasi suatu hal tertentu. Grice (1975: 44) memaparkan contoh sebagai berikut.

(3) He is an English man, he is therefore, brave.

'Dia seorang laki-laki Inggris, karena itu dia berani'. 
Implikatur Percakapan muncul dalam suatu tindak percakapan. Oleh karena itu sifatnya temporer (terjadi saat berlangsung tindak percakapan), dan non konvensional (sesuatu yang diimplikasikan tidak mempunyai relasi langsung dengan tuturan yang diucapkan (Levinson, 1991: 117) .

Menurut Grice (1975: 45) ada seperangkat asumsi yang melingkupi dan mengatur kegiatan percakapan sebagai suatu tindak berbahasa (speech act). Menurut analisisnya, perangkat asumsi yang memandu tindakan orang dalam percakapan itu adalah "prinsip kerjasama" (cooperative principle). Dalam melaksanakan "kerja sama" tindak percakapan, setiap penutur harus mematuhi empat maksim percakapan (maxim of conversation) yakni (1) maksim kuantitas, (2) maksim kualitas, (3) maksim relevansi, (4) maksim cara. Penjelasan keempat maksim tersebut adalah sebagai berikut:

\section{Maksim Kuantitas (The Maxim of Quantity)}

Maksim kuantitas menghendaki penutur untuk memberikan kontribusi yang secukupnya atau sebanyak informasi yang dibutuhkan. Berikut ini adalah contoh maksim kuantitas.

(4) a. Ali : Nama kamu siapa?

b. Evi : Nama saya Evi. Kelas tiga SD Cemara Dua. Rumah saya di Pasar Kliwon. Bapak saya seorang polisi. Ibu saya seorang ibu rumah tangga.

Agar percakapan di atas memenuhi prinsip kuantitas, Evi tidak perlu mengungkapkan dirinya secara lengkap karena Ali hanya menanyakan nama saja. Seharusnya Evi hanya menyebutkan namanya saja, tanpa mengungkapkan jawaban yang lain.

2. Maksim Kualitas (The Maxim of Quality)

Maksim kualitas menekankan tentang kewajiban penutur untuk mengatakan hal yang sebenarnya. Kontribusi penutur haruslah berisi kebenaran yang dapat dipertanggungjawabkan.

(5) a. Pak Guru : Dalam sehari terdapat berapa jam?

b. Siswa : 30 jam.

c. Pak Guru : Ya, selamat kamu telah dapat bonus tambahan enam jam ya.

Tuturan pak Guru (5c) Ya, selamat kamu telah dapat bonus tambahan enam jam ya dimaknai sebagai bantahan atas jawaban siswa yang salah. Harusnya siswa menjawab 24 jam. Dengan melihat tuturan pak guru, siswa akan berpikir bahwa tidak mungkin dalam sehari semalam terdapat tambahan jam.

3. Maksim Relevansi (The Maxim of Relevance)

Maksim relevansi mengharuskan peserta percakapan memberikan kontribusi yang sesuai atau relevan dengan pembicaraan. Agar lebih jelas, perhatikan contoh di bawah ini.

(6) a. Tony : Pak, ada tabrakan motor lawan truk di pertigaan depan.

b. Bapak : Yang menang apa hadiahnya?

(I Dewa Putu Wijana, 1996:49)

Percakapan antara Tony dan bapaknya tentang peristiwa kecelakaan lalu lintas di pertigaan depan. Tabrakan terjadi antara sepeda motor lawan sebuah truk. Kecelakaan umumnya menimbulkan korban, baik korban luka maupun korban meninggal. Seharusnya bapak menanyakan apakah terjadi korban dari kecelakaan itu. Bukan menanggapinya dengan menanyakan hadiah bagi pemenang. Karena dalam kecelakaan tidak ada menang atau kalah.

4. Maksim Pelaksanaan/ Cara (The Maxim of Manner)

Maksim pelaksanaan mengharuskan setiap peserta percakapan berbicara secara langsung, tidak kabur, tidak taksa, tidak berlebih-lebihan, runtut, singkat-padat, dan secara tertip-teratur.

(7) a. Tina : : Masak Peru ibukotanya Lima. Banyak amat.

b. Andi : Bukan jumlahnya, tetapi namanya.

(I Dewa Putu Wijana, 1996:51)

Dalam konteks percakapan di atas, yang dimaksud dengan Lima bukanlah berarti "nama 
bilangan', melainkan Lima adalah nama ibukota negara Peru. Dalam pragmatik tidak dikenal adanya ambiguitas. Ambigu harus dihindari dalam pragmatik.

Selain memahami maksim -maksim percakapan, implikatur juga membutuhkan beberapa perangkat untuk memahaminya. Perangkat ini akan akan membantu mitra tutur untuk memahami tuturan penutur. Diantara perangkat untuk memahami implikatur adalah (1) Praanggapan, (2) Inferensi, (3) Referen, dan (4) Interpretasi lokal dan analogi.

Praanggapan memegang peranan penting dalam analisis wacana. Praanggapan yang tidak tepat dalam penggunaannya akan mengganggu koherensi atau keruntutan wacana. Kesalahan membuat praanggapan dapat mengakibatkan kesalahan dalam menerima implikatur. Sebaliknya, semakin tepat praanggapan yang digunakan,semakin komunikatif pula sebuah ujaran (Abdul Rani, Bustanul Arifin, Martutik, 2006:168).

Inferensi atau penarikan simpulan menurut Gumperz adalah proses interpretasi yang ditentukan oleh situasi dan konteks percakapan. Dengan demikian inferensi tidak hanya ditentukan oleh mitra tutur, melainkan juga menghendaki konteks situasi. Penarikan inferensi akan sulit untuk dilakukan bila baik mitra tutur dan konteks situasi maupun salah satu di antara keduanya tidak sinkron. Ketidakjelasan konteks juga mempersulit pengambilan inferensi (Abdul Rani, Bustanul Arifin, Martutik, 2006:168).

Selanjutnya, memahami referen pada suatu percakapan dapat diamati pada percakapan berikut:

(8) a : Kemarin si pelangi mati

$\mathrm{b}$ : Digigit ular?

Antara a dan $b$ telah memahami bahwa percakapan mereka adalah seputar ayam milik a yang diberi nama pelangi. a mengatakan pada $b$, bahwa ayamnya mati. $b$ mengetahui bahwa a mempunyai ayam yang diberi nama pelangi. Ayam bernama pelangi itulah yang objek yang dirujuk oleh percakapan a dan b.

Prinsip interpretasi lokal menekankan pada upaya untuk menginterpretasikan sebuah tuturan dengan melihat konteks yang ada di sekitar tuturan itu. Baik konteks yang melekat pada tuturan itu sendiri maupun konteks yang ada di sekelilingnya. Sedangkan prinsip analogi lebih menekankan pada pengalaman yang dimiliki oleh pendengar atau mitra tutur.

\section{METODE PENELITIAN}

Penelitian implikatur pada percakapan Sinetron Para Pencari Tuhan (PPT) Jilid I ini merupakan penelitian kualitatif. Data dalam penelitian ini adalah implikatur percakapan yang terdapat dalam tuturan pemain sinetron $P P T$ Jilid I. Adapun implikatur percakapan itu diketahui dengan mengenali adanya makna yang tersirat pada tuturan penutur.

Sumber data penelitian ini adalah Sinetron Para Pencari Tuhan Jilid I. Karena terbatasnya penelitian dan waktu, peneliti hanya membatasi pengambilan data pada episode 1. Sinetron ini diproduksi oleh PT Demi Gisela Citra Sinema, cerita dan skenario ditulis oleh Wahyu HS ("Lorong Waktu", "Demi Masa"), dan disutradarai oleh Deddy Mizwar dan Kiki ZKR.

Data penelitian diperoleh dengan menggunakan teknik dokumentasi. Teknik ini diawali dengan cara menyimak seluruh implikatur percakapan dalam Sinetron PPT Jilid I. Selanjutnya, peneliti mencatat seluruh data yang terkait dan mengklasifikan data tersebut serta mencatat kembali dalam kartu data.

Teknik analisis data yang digunakan dalam penelitian ini adalah model analisis mengalir atau flow model of analisis. Ada empat komponen dalam model analisis mengalir, yaitu pengumpulan data, reduksi data, penyajian data, dan penarikan simpulan atau verifikasi. 


\section{TEMUAN DAN PEMBAHASAN}

Peneliti menemukan adanya pengambangan maksim dalam percakapan antar tokoh dalam Sinetron Para Pencari Tuhan Jilid I. Pengambangan tuturan pada percakapan tersebut, mengambang pada maksim- maksim tertentu. Berikut penjelasan dari pengambangan maksim tersebut.

\section{Maksim Kualitas}

Setiap percakapan menghendaki peserta tutur untuk memberikan kontribusi yang dapat dipertanggungjawabkan kebenarannya. Maksim kualitas menghendaki penutur maupun mitra tutur mengatakan tuturan yang benar dan dapat dipertanggungjawabkan.

Kontribusi yang diberikan hendaknya didasarkan pada bukti-bukti yang memadai. Percakapan antar pemain pada Sinetron PPT Jilid I ini mengandung tuturan yang pada dasarnya memberikan kontribusi kebenaran. Akan tetapi, kandungan kebenarannya masih mengambang.

Percakapan berikut juga menunjukkan adanya pengambangan pada maksim kualitas. Percakapan ini menceritakan kejadian Barong, Juki, dan Chelsea yang baru selesai wudhu. Setelah selesai wudhu, kemudian mereka masuk ke mushola. Pada waktu berada di depan pintu mushola, mereka bertiga bertemu dengan Pak Hansip (Udin) dan terjadi percakapan berikut ini.

(9) a. Pak Hansip : perasaan pernah ketemu, dimana ya??

b. Chelsea : Di istana negara kali, waktu upacara bendera (sambil mereka bertiga saling berpandangan).

Percakapan pada data (9), tampak respon dari Chelsea (9) b Di istana negara kali, waktu upacara bendera sudah memberikan kontribusi dalam percakapan dengan memberikan jawaban tersebut dan memenuhi maksim kerjasama. Akan tetapi, apabila diperhatikan dari konteks situasi atau interpretasi konteks sekitarnya, Barong, Juki, dan Chelsea baru bertemu dengan Pak Hansip dan hal ini sepertinya tidak mungkin terjadi apabila mereka bertemu sebelumnya di Istana negara. Pengambangan pada maksim kualitas ini juga didukung oleh respon dari ketiga pemuda itu dengan respond ekstralingual dari ketiga pemuda tersebut dengan saling berpandangan setelah Chelsea menuturkan jawaban kepada Pak Hansip. Hal ini mengindikasikan bahwa kemungkinan mereka belum pernah bertemu, dan hal yang dituturkan Chelsea merupakan pengungkapan implikatur bahwa mereka belum pernah bertemu sebelumnya.

Selain data percakapan di atas percakapan berikut ini juga menunjukkan adanya pengambangan pada maksim kualitas. Percakapan berikut menceritakan Bang Jack beserta muridnya terlambat bangun sahur dan waktu sahur tinggal lima menit.
(10) a. Bang Jack
: Kita sahur buruan.!!!
b. Chelsea
: Kita sahur apaan Bang?
c. Bang Jack
Teh manis apa kopi Bang?
: Sirup Markisa (sambil menuju ke tempat berwudhu)

Jawaban Bang Jack terhadap pertanyaaan Chelsea di atas menunjukkan adanya kontribusi dalam percakapan dan terpenuhinya maksim kerjasama. Akan tetapi, apabila diperhatikan dari interpretasi konteks sekitarnya, kebenaran jawaban Bang Jack mengalami pengambangan, karena tidak sesuai dengan interpretasi konteks setelahnya. Bang Jack menjawab bahwa mereka akan sahur sirup markisa, tetapi mereka menuju tempat wudhu. Selanjutnya, konteks 
peristiwa setelah itu menunjukkan tidak adanya kesesuaian konteks dengan jawaban Bang Jack. Ternyata Jawaban sirup markisa tersebut bermakna ‘minum dari air kran’ .

\section{Maksim Cara}

Menurut Grice, setiap penutur yang terlibat dalam sebuah percakapan dapat dipastikan menaati prinsip kerja sama. Dalam mentaati prinsip kerja sama ini, penutur dapat menggunakan berbagai pilihan cara untuk menunjukkan kepatuhannya terhadap prinsip kerja sama. Salah satu pilihan yang dapat dilakukan adalah menggunakan cara atau teknik tertentu. Penutur dapat menggunakan kalimat langsung maupun tak langsung. Namun, menggunakan cara tersebut kadang menjadikan tuturan tampak bias atau mengambang sehingga mengakibatkan prinsip kerja sama tampak tidak terpatuhi. Fenomena semacam ini tidak disebut sebagai pelanggaran prinsip kerja sama, melainkan pengambangan maksim. Sinetron PPT Jilid I mengandung beberapa percakapan yang di dalamnya terdapat pengambangan maksim ini. Berikut contoh pengambangan maksim cara yang terdapat dalam percakapan antar pemain.

Percakapan ini menceritakan bahwa setelah Barong, Juki, dan Chelsea mngetahui tidak ada warung makan yang buka karena puasa. Mereka bertiga memutuskan untuk minum di mushola dengan berpura-pura wudhu di sana. Akan tetapi, ternyata sewaktu mereka sedang minum di tempat wudhu, Bang Jack kebetulan juga ingin wudhu sehingga mengetahui aktifitas mereka.

(11) a. Bang Jack: Astaghfirullahal'adhim....wudhu model mana ni.

He...Loe whudhu apa minum? Kalau wudhu airnya jangan ditelen, bisa batal puasa loe. Munntahin...Muntahin (Dengan suara tinggi).

Loe baru masuk Islam yaa? (sambil berjalan mendekat tmpat wudhu)

b. Barong : Baru keluar penjara sih.

c. Bang Jack: Perhatiin cara wudhu gue..(sambil menuju kran air dan berwudhu)

Percakapan pada data (11) b di atas menunjukkan bahwa Barong menerapkan prinsip kerja sama dalam memberikan jawaban atas pertanyaan Bang Jack Baru keluar penjara sih... Akan tetapi, jawaban yang diberikan Barong tersebut kurang sesuai dengan pertanyaan dari Bang Jack Loe baru masuk Islam yaa?. Pertanyaan dari Bang Jack ini menghendaki adanya jawaban 'ya' atau 'tidak' beserta alasannya.

Pertanyaan Bang Jack di atas Loe baru masuk Islam yaa?, muncul atas pra anggapan yang muncul dari Bang Jack ketika melihat Barong, Juki, Chelsea di tengah hari waktu bulan puasa minum dari air kran wudhu. Jawaban implikaturpun muncul dari Barong Baru keluar penjara sih. Jawaban ini sebenarnya kurang' sesuai dengan pertanyaan Bang Jack tetapi telah memberikan kontribusi dalam maksim kerjasama. Jawaban Barong ini muncul dalam beturan bentuk tuturan tidak langsung, sehingga tampak tidak sesuai dengaan pertanyaan atau ada pengambangan. Jawaban implikatur dari Barong ini dapat ditafsirkan bahwa mereka bertiga sebenarnya Islam tetapi kondisi pemahaman keislaman mereka kurang karena mereka mantan narapidana. Setelah adanya implikatur tersebut, percakapan tetap berlanjut dengan adanya respond dari Bang Jack Perhatiin cara wudhu gue.. Respond ini muncul karan Bang Jack memiliki pra anggapan atas kondisi mereka bertiga dan mengambil inferensi atas tuturan Barong.

Selain pada percakapan di atas, pengambangan maksim cara juga terdapat pada percakapan antar pemain di bawah ini. Diceritakan bahwa malam itu, Barong, Juki, dan Chelsea tidur di Mushola menemani Bang Jack. Mereka bertiga bergantian untuk berjaga di mushola. Ketika tiba waktu Juki berjaga, tiba-tiba Pak Hansip (Pak Udin) muncul di depan masjid sambil melepaskan sepatu. Jukipun kaget dengan kedatangan Pak Hansip. 
(12) a. Juki : Pak Hansip mau tidur sini juga?

b. P. Hansip : Bentar lagi shubuh, masih mikirin tidur..

c. Juki : Shubuh.....Emang jam berapa sekarang?

d. P. Hansip : Lima menit lagi sudah sholat shubuh

Percakapan pada data 12 di atas menunjukkan adanya pertanyaan dari Juki Shubuh.....Emang jam berapa sekarang?. Kemudian, jawaban berupa pengambangan maksim cara diberikan Pak Hansip Lima menit lagi sudah sholat shubuh. Jawaban Pak Hansip ini sebenarnya sudah menerapkan prinsip kerja sama dalam percakapan tersebut dengan memeberikan keterangan waktu secara implisit. Akan tetapi, jawaban yang diberikan Pak Hansip tersebut kurang sesuai dengan pertanyaan Juki yang menghendaki jawaban 'waktu saat itu, yang menunjukkan pada jam tertentu'.

Tuturan Pak Hansip pada tuturan Lima menit lagi sudah sholat shubuh merupakan jawaban dari pertanyaan Juki yang menanyakan jam. Jawaban tersebut disampaikan secara tidak langsung. Dalam hal ini, sebenarnya jawaban tersebut sudah memberikan kontribusi jawaban pada pertanyaan Juki secara implisit, tetapi kurang sesuai dengan jawaban yang dikehehndaki Juki. Setelah adanya jawaban dari Pak Hansip, percakapan tetap berlangsung dengan adanya respond dari Juki untuk membangunkan teman-temannya sahur. Hal ini merupakan indikasi bahwa implikatur tersebut dipahami oleh mitra tutur (Juki).

\section{Maksim Relevansi}

Penutur dan mitra tutur selalu mengharapkan peserta percakapan mengucapkan tuturannya sesuai dengan konteks yang ada di sekitar percakapan itu. Tuturan yang sesuai dengan konteks akan memudahkan lawan tutur memahami apa yang dituturkan oleh penutur. Namun kadangkala penutur maupun mitra tutur karena telah saling mengetahui informasi atau latar belakang tertentu, mereka dapat langsung mengucapkan suatu tuturan tanpa mengutarakan latar belakangnya.Percakapan dalam Sinetron PPT Jilid I mengandung beberapa tuturan yang mengalami pengambangan dalam relevansi, hal ini dibuktikan dengan tuturan yang kurang sesuai dengan konteks tetapi masih dipahami oleh penutur dan mitra tutur.

Percakapan berikut menceritakan bahwa setelah Barong keluar dari penjara, Barong pulang ke rumahnya untuk menemui ibunya. Akan tetapi, ibunya ternyata tidak menerima Barong dan mengusir Barong dari rumah.

(13) a. Mak Juki : Dari kecil kerjaannya cuma bikin malu orang tua

Babe loe meninggal hanya gara-gara mikirin loe..(sambil mengangkat kayu yang akan dipukulkan ke Juki)

b. Juki : Tuhan yang nyabut nyawa Babe Mak...jangan salahin Juki

c. Mak Juki : (sambil memukulkan pemukul ke tiang)

Masih berani ngebantah loe ya?

Percakapan antara Juki dan Mak Juki diatas tampak respon dari Juki (13) b. Tuhan yang nyabut nyawa Babe Ma..jangan salahin Juki tidak sesuai dengan tuturan dari Mak Juki (13) a. Babe loe meninggal hanya gara-gara mikirin loe. Jawaban tersebut sebenarnya telah memberikan kontribusi dari tuturan yang diucapkan Mak Juki. Akan tetapi, respond Juki tersebut tidak menunjukkan kesesuaian dengan tuturan Mak Juki. Sehingga, kondisi kesal Mak Juki yang sebelumya sudah merasa kesal menjadi bertambah kesal dengan menuturkan (13) c Masih berani ngebantah loe ya? , sambil memukulkan pemukul ke tiang dan mengusir Juki dari rumah. 
Adanya implikatur pada percakapan di atas Tuhan yang nyabut nyawa Babe Ma, tetap memberikan kontribusi dalam percakapan dan dipahami oleh mitra tutur walaupun ada ketidaksesuaian dalam konteks. Hal ini karena pada mitra tutur (Mak Juki) sudah ada praanggapan bahwa memang kematian hanya ditangan Tuhan. Akan tetapi, Mak Juki menitik beratkan pada penyebab kematian Babe Juki (secara fisik), karena memikirkan Juki. Sehingga, sebenarnya ada pengambangan dalam hal relevansi respond dari Juki dan Mak Juki. Juki menuturkan respond berupa kematian secara alamiah secara sekaligus sebagai pembelaan diri, sedangkan Mak Juki menuturkan alasan kematian Babe Juki (secara fisik ) menurut Mak Juki. Selanjutnya, respond Mak Juki yang tampak kesal terhadap Juki menunjukkan bahwa dengan adanya implikatur dalam percakapan di atas, mitra tutur tetap memahami maksud penutur karena ada pra-anggapan pada mitra tutur.

\section{SIMPULAN}

1. Implikatur pada percakapan pemain Sinetron Para Pencari Tuhan Jilid I ditemukan pada lima percakapan.Tuturan pada lima percakapan tersebut menunjukkan adanya pengambangan pada maksim kualitas(dua tuturan), maksim cara (dua tuturan), dan maksim relevansi (satu tuturan).

2. Pengambangan pada percakapan Sinetron PPT Jilid I ini dipengaruhi oleh beberapa hal. Dari analisis yang dilakukan, diketahui adanya praanggapan yang sama, penutur mereferen pada referen tertentu, dan digunakannya interpretasi lokal, menjadi latar belakang terjadinya pengambangan.

\section{DAFTAR PUSTAKA}

Brown, Gillian and George Yule. 1983. Discourse Analysis. Cambrigde: Cambridge University Press

Abdul Rani, Bustanul Arifin, Martutik. 2006. Analisis Wacana. Malang: Bayumedia

Chaer, Abdul. 20I0. Kesantunan Berbahasa. Jakarta: Rineka Cipta.

Grice, H.Paul. Logic and Conversation, dalam Cole and JL Morgan, Syntax and Semantics Vol.3: Speech Act. New York: Acadmy Press

Hasan Lubis, Hamid. Analisis Wacana Pragmatik. Medan: Angkasa Bandung

Levinson, Stephen C. 1991. Pragmatics. Cambrigde: CUP

Nadar, FX. 2008. Pragmatik dan Penelitian Pragmatik. Yogyakarta. Graha Ilmu

Rustono. 1999. Pokok-Pokok Pragmatik. Semarang: CV. IKIP Semarang Press

Samsuri. 1991. Analisis Bahasa. Jakarta / Erlangga.

Sudaryono. 1993. Negasi dalam Bahasa Indonesia: Suatu Tinjauan Sintaksis dan Semantik. Jakarta: Pusat Bahasa

Sulistyo, Edi Tri. 2013. Pragmatik: Suatu Kajian Awal. Surakarta: UNS Press

Wijana, I Dewa Putu. 1996. Dasar-dasar Pragmatik. Yogyakarta: Andi Yogyakarta.

\section{Virtual References}

http://ppt.sctv.co.id/jilid/jilid-1/, Diakses 1/7/2016; 15.00 